\title{
PEMURIDAN SEBAGAI MANDAT MISI MENURUT MATIUS 28:18-20
}

\author{
Patrecia Hutagalung \\ Sekolah Tinggi Alkitab Tiranus \\ Jl. Cihanjuang Km. 5,2, Cihanjuang, Parongpong, Bandung Barat \\ petti.hutagalung@gmail.com
}

\begin{abstract}
ABSTRAK: Salah satu perintah Tuhan Yesus yang harus ditaati dan dilakukan oleh setiap orang percaya adalah Amanat Agung yang terus dipertahankan orang-orang Kristen sampai saat ini. Tidak sedikit gereja-gereja yang mengerahkan kekuatannya untuk melaksanakan Amanat Agung dengan berbagai cara yang kreatif dan kekinian. Namun fenomena yang ada, seringkali Amanat Agung dijalankan sebagai suatu program atau proses "pemberitaan", yang cenderung menekankan "pergi" berpindah dari satu tempat ke tempat lainnya tetapi mengesampingkan pemuridan. Tanpa mempermasalahkan kegiatan pergi untuk melaksanakan proses penginjilan, tetapi pemuridan merupakan proses yang tidak dapat lepas dari pertimbangan kerangka pelayanan. Dalam Matius 28:18-20, "memuridkan" adalah kata kerja yang menjadi inti dari Amanat Agung. Metode penelitian yang digunakan dalam artikel ini adalah metode kualitatif yang meneliti sumber-sumber terkait dan mengkaji Matius 28:18-20 sebagai landasan Amanat Agung. Hasil penelitian ini akan menyimpulkan bahwa Amanat Agung adalah proses penginjilan yang bersifat berkelanjutan untuk mengajar mereka yang telah percaya kepada Tuhan Yesus, menjadi murid Kristus yang akan menghasilkan murid Kristus selanjutnya.
\end{abstract}

Kata Kunci: pemuridan, murid kristus, misi, amanat agung, injil matius

\section{DISCIPLESHIP AS A MANDATE OF MISSION ACCORDING TO MATTHEW 28:18-20}

\begin{abstract}
One of the commands of Jesus that must be obeyed and carried out by every believer is the Great Commission that Christians continue to maintain today. Many churches that exert their energy to carry out the Great Commission in a variety of creative and contemporary ways. However, the phenomenon, often the Great Commission is carried out as a program or process of "preaching", which tends to emphasize "go" move from one place to another but overrides discipleship. There is no question about the activities go in the evangelistic process, but discipleship is a process that cannot be separated from the thought of ministry framework. In Matthew 28:18-20, "discipleship" is the verb that forms the core of the Great Commission. The research method used in this article is a qualitative method that examines related sources and Matthew 28:19-20 as the foundation of the Great Commission. The results of this study will conclude that the Great Commission is a process of evangelism that is continuous to teach those who have believed in the Lord Jesus, become disciples of Christ who will also produce disciples of Christ.
\end{abstract}

Keywords: discipleship, disciples of christ, mission, great commission, the gospel of matthew

\section{PENDAHULUAN}

Amanat Agung dalam Matius 28:18-20 merupakan perintah yang disampaikan langsung oleh Tuhan Yesus kepada murid-murid-
Nya sebelum la naik ke surga. Di mana dalam perintah itu Tuhan Yesus mengatakan kepada setiap murid yang masih berada di bumi untuk pergi, menjadikan segala bangsa 
murid-Nya, membaptis mereka dan mengajar mereka untuk melakukan segala sesuatu yang telah diperintahkan oleh Tuhan Yesus kepada mereka. Dengan kata lain, meneruskan apa yang telah dilakukan oleh Tuhan Yesus, yaitu memberitakan Kerajaan Sorga. Bagian akhir dari perintah Tuhan Yesus yang terdapat dalam Injil Matius ini mengacu pada penekanan untuk pengajaran. Murid-murid mewartakan Kabar Baik dan menjadikan mereka yang telah menerima keselamatan untuk menjadi murid Kristus selanjutnya. Pengajaran yang dikehendaki oleh Tuhan Yesus adalah pengajaran yang berkaitan erat dengan pemuridan.

Matius memandang pemuridan sebagai suatu hal yang sentral, terlihat jelas dalam tulisannya yang menyiapkan ruang cukup panjang tentang ajaran Tuhan Yesus. "Jadikanlah semua bangsa murid-Ku" dan "ajarlah mereka" merupakan perintah yang tidak dapat dipisahkan dari Mandat Misi. Ketertarikan Matius terhadap pola pemuridan Tuhan Yesus yang turut menekankan relasi guru dengan para murid membuat makna pemuridan menjadi signifikan. Artinya pemuridan yang Tuhan Yesus lakukan selama pelayanan-Nya bersifat intens yang terlihat dari relasi bersama dengan murid-murid-Nya. Setiap murid diajak untuk mengikut Dia dan hidup bersama-Nya selama masa pelayananNya. Artinya setiap murid yang terpilih tidak hanya menjadi pendengar melainkan dipanggil untuk menjadi murid-murid-Nya.

Dalam kaitannya dengan mandat misi, Matius memandang penginjilan bukan sekadar upaya para murid untuk menjadikan orang lain Kristen atau hanya fokus dengan kata pergi untuk mewartakan, tetapi memahami kabar keselamatan sebagai anugerah istimewa bagi mereka yang memberi diri untuk menjadi murid Kristus. Memang benar bahwa Amanat Agung merupakan misi Allah bagi se- tiap orang percaya untuk memberitakan kabar keselamatan, namun inti dari mandat tersebut terletak pada pemuridan sebagai suatu tugas pemberitaan keselamatan yang harus dikerjakan bagi seluruh bangsa (Darmawan, 2019, p. 145). Signifikansi pemuridan sebagai mandat misi dalam artikel ini didasarkan pada esensi perintah Tuhan Yesus yang adalah untuk menjadikan segala bangsa murid (Mat. 28:19-20). Ketika akhirnya para rasul melaksanakan perintah tersebut, mereka tidak hanya membentuk program untuk pergi ke suatu tempat, tetapi para rasul mempertimbangkan proses pemuridan agar komunitas orang percaya tidak sekadar bertambah tetapi terus bertumbuh secara spiritual untuk menjadi saksi-saksi Kristus selanjutnya. Implikasinya adalah gerejagereja melakukan pemuridan sebagai upaya untuk mempersiapkan generasi selanjutnya yang berkualitas secara rohani untuk menghadapi tantangan zaman dan menjadi saksi Kristus yang setia.

Artikel ini bertujuan untuk menjelaskan bahwa Amanat Agung tidak berhenti pada kegiatan untuk sekadar pergi menjangkau jiwa di beberapa tempat-tempat tertentu, tetapi Amanat Agung adalah upaya setiap murid Kristus untuk memberitakan kabar keselamatan bagi segala bangsa dan menjadikan mereka yang telah percaya menjadi murid-murid Kristus selanjutnya. Sehingga Amanat Agung dapat dipahami dengan lengkap sesuai dengan maksud dari pesan itu mula-mula diberikan. Untuk mencapai tujuan tersebut penulis akan mengkaji Matius 28:1820 yang merupakan landasan Amanat Agung sebagai mandat misi untuk pergi memberitakan Injil dan menjadikan segala bangsa murid Kristus yang melakukan segala sesuatu yang telah diperintahkan-Nya kepada mereka. 


\section{METODE PENELITIAN}

Untuk menemukan hasil penelitian, penulis menggunakan metode kualititaf, atau studi kepustakaan, atau yang biasa disebut Library Research. Menurut Sarwono, studi kepustakaan merupakan suatu studi pengumpulan data-data berupa dokumen-dokumen yang ada di perpustakaan (Sarwono, 2006, p. 26). Studi kepustakaan juga dapat berupa analisis dari buku atau jurnal referensi dan hasil-hasil penelitian sebelumnya yang terkait dengan pembahasan yang sedang dilakukan untuk mendapatkan landasan teori atau menemukan teori baru dari masalah yang akan dan sedang diteliti. Penulis menggunakan metode kepustakaan yang akan mengumpulkan data-data dari jurnal dan buku yang berkaitan dengan topik penelitian sebagai sumber informasi pendukung untuk dianalisa menjadi landasan teori dari pembahasan dalam penelitian ini. Setiap data yang dikumpulkan akan dikaji dan dianalisis. Penulis akan memberikan tanggapan terhadap sumber informasi yang telah dianalisis tersebut sebagai pendukung pendapat penulis yang akan menghasilkan suatu teori berkaitan dengan topik yang dibahas.

Secara keseluruhan, penulis melakukan kajian terhadap nats Matius 28:18-20. Nats tersebut menjadi landasan bagi topik bahasan. Penulis juga akan menggunakan referensi dari ayat-ayat lain yang relevan. Dalam artikel ini, penulis akan menjabarkan ayat demi ayat yang terambil dari Matius 28:18-20. Akan dilakukan studi kata yang menyoroti empat kata perintah, yakni pergilah, jadikanlah murid, baptislah dan ajarlah. Analisa terhadap nats tersebut juga dikembangkan dengan memperhatikan konteks jauh dan konteks dekat. Proses analisa ini akan juga mendalami beberapa pendapat penulis lain yang melakukan studi terhadap topik yang serupa.

\section{HASIL DAN PEMBAHASAN}

\section{Kajian Terhadap Matius 28:18-20 Sebagai Amanat Agung}

Misi memberitakan Kerjaan Sorga yang lebih dikenal sebagai Amanat Agung merupakan topik yang penting dalam teologi Matius. Matius telah menempatkan tema misi sejak awal pelayanan Yesus (Lowery, 2011, p. 42). Setelah Tuhan Yesus dibaptis, dicobai oleh Iblis, Tuhan Yesus tampil di Galilea, sebagai awal pelayanan-Nya dan itulah kali pertama Tuhan Yesus memberitakan Kerajaan Sorga menyuarakan pertobatan yaitu kabar keselamatan (3:17). Matius membawa pembaca untuk memahami berita "Kerajaan Sorga" sebagai suatu hal yang penting, khususnya dalam misi dan ajaran Tuhan Yesus. Karena pekerjaan dan misi yang besar maka Tuhan Yesus mempersiapkan orang-orang terpilih untuk diajar secara khusus dan menjadi murid-murid Kristus yang di hari depan merekalah yang akan meneruskan pelayanan yang telah dilakukan Tuhan Yesus. Muridmurid yang dipanggil dan kemudian mengikut Dia (4:22), diperintahkan untuk meneruskan berita "Kerajaan Sorga" yang telah la mulai selama masa pelayanan-Nya di bumi sebelum la naik ke sorga. Selama masa pelayanan Tuhan Yesus, la mengajar dan mengajak murid-murid-Nya untuk hidup seperti Dia. Di sinilah makna pemuridan itu terlihat, yaitu Tuhan Yesus mempersiapkan mereka untuk meneruskan ajaran yang telah mereka terima saat ikut melayani bersama Tuhan Yesus. Matius yang sangat tertarik dengan relasi Yesus dengan para murid kemudian menutup tulisannya dengan sebuah perikop yang mengatakan bahwa murid-murid diberikan perintah, yaitu Amanat Agung sebagai tugas dan misi yang harus dilanjutkan oleh para murid. Suatu misi yang bukan hanya dilakukan dalam secara situasional tetapi 
merupakan mandat untuk memuridkan setiap orang yang harus dilakukan dalam setiap gerak kehidupan.

\section{Matius 28:18-20}

Yesus mendekati mereka dan berkata: "Kepada-Ku telah diberikan segala kuasa di sorga dan di bumi. Karena itu pergilah, jadikanlah semua bangsa murid-Ku dan baptislah mereka dalam nama Bapa dan Anak dan Roh Kudus, dan ajarlah mereka melakukan segala sesuatu yang telah Kuperintahkan kepadamu. Dan ketahuilah, Aku menyertai kamu senantiasa sampai kepada akhir zaman" (Mat. 28:19-20)

Setelah murid-murid sampai di bukit di Galilea, mereka bertemu dengan Tuhan Yesus dan menyembah-Nya. Melihat bahwa beberapa dari mereka masih ragu, Tuhan Yesus mendekati mereka dan menjawab sikap skeptis tersebut dengan suatu penegasan, bahwa segala kuasa sudah ada dalam tangan-Nya (28:18). Tuhan Yesus menjawab keraguan beberapa di antara mereka yang menyembah-Nya dengan otoritas yang sudah ada pada-Nya. Kebangkitan-Nya melahirkan otoritas di surga dan di bumi, mandat misi yang la sampaikan merupakan penegasan bahwa la adalah pemegang otoritas tertinggi. Tuhan Yesus memulai mandat-Nya dengan memberitahukan kepada para murid bahwa seluruh kuasa telah diserahkan kepada-Nya maka mereka tidak perlu ragu untuk melakukan tugas yang besar, yaitu memberitakan Kerajaan Sorga kepada seluruh bangsa (28:18).

Keistimewaan para murid terlihat sebagai orang-orang yang menempati posisi utama dalam misi Kerajaan Allah untuk diteruskan kepada komunitas selanjutnya, sampai ke ujung bumi (Darmawan, 2019, p. 146). Sebagaimana yang dicatat dalam Kisah Para Rasul, mulai dari diberikannya tugas
Amanat Agung, para murid bergerak memberitakan Injil dan mengajar banyak orang. Mencetak murid-murid dan pengikut untuk dibimbing dan diajarkan sesuai dengan apa yang telah mereka terima dari Tuhan Yesus. Sehingga komunitas semakin besar dan bertambah banyak seperti yang dikehendaki oleh Guru mereka (Kis:14-47).

Sebagaimana yang dikatakan oleh Darmawan, komunitas orang percaya yang semakin besar tersebut kemudian berkomitmen untuk meneruskan ajaran Yesus sebagai bentuk ketaatan mereka untuk memberitakan Injil kepada segala bangsa lalu menetapkan hati untuk bertekun dalam pengajaran para rasul (Darmawan, 2019, p. 146). Artinya, sejak para rasul mulai membentuk komunitas orang percaya, mereka telah mempertimbangkan pemuridan. Perluasan komunitas Kristen terus berlanjut sampai hari ini dan relevan untuk gereja-gereja masa kini, termasuk panggilan untuk memuridkan. Lantas, bagaimana gereja masa kini perlu memaknai perintah pergi dalam Amanat Agung?

\section{“Pergilah"}

Frasa "karena itu" dalam ayat 19 merupakan akibat dari ayat sebelumnya, yaitu penegasan otoritas Tuhan Yesus. Ayat 19 sedang menjelaskan bahwa hal ini terjadi disebabkan oleh ayat sebelumnya. Sebelum para murid diberikan suatu perintah, Tuhan Yesus memilih untuk mengatasi rasa khawatir dan keraguan mereka terlebih dahulu, dengan pernyataan bahwa segala kuasa telah ada dalam tangan Yesus. Oleh sebab itu, para murid diberikan suatu tugas untuk pergi. Kata "pergilah" dalam bahasa Yunani menggunakan kata poreuthentes yang merupakan kata kerja yang memiliki arti "pergi".

Matius 28:18-20 dipahami sebagai Amanat Agung untuk pergi memberitakan Injil. Pemahaman yang terbangun adalah dari 
titik fokus yang mengacu pada awal kalimat perintah yaitu kata "pergilah" (Darmawan, 2019, p. 145). Darmawan menjelaskan bahwa pekerjaan misi tidak berhenti pada kata pergilah melainkan terdapat pesan lanjutan yang tidak kalah penting yaitu pemuridan. Perintah pergi sebagai perintah yang pertama disebutkan, adalah bentuk tindakan para murid untuk memberitakan Kabar Baik. Artinya, para murid "pergi" terlebih dahulu untuk memberitakan Injil. Jika melihat teks Matius 28:19 dengan menggarisbawahi kata "semua bangsa" terlihat jelas bahwa Tuhan Yesus menghendaki berita itu tersebar ke segala penjuru bumi. Oleh sebab itu Tuhan Yesus memberikan perintah kepada para murid-Nya untuk pergi, karena jangkauan mereka adalah semua bangsa. Tuhan Yesus mengacu pada apa yang telah la lakukan terlebih dahulu semasa pelayanan-Nya di bumi yaitu "pergi", tidak heran la memberikan perintah tersebut sebagai bentuk delegasi kepada murid-muridNya untuk mengikuti teladan hidup-Nya.

Sementara dalam terjemahan lain kata "pergi" menggunakan 'to go', 'travel' dan 'proceed'. Tetapi perlu digarisbawahi kata "pergilah" merupakan kata kerja dalam bentuk pasif yang kemudian berubah bentuk kata sesuai dengan kata selanjutnya yaitu matheteusate. Artinya, perintah "pergilah" tidak dapat dikatakan sebagai kata kerja utama. Bartholomeus Diaz (2014) menjelaskan:

Kata "pergilah" seakan-akan merupakan kata kerja pokok yang mengindikasikan inti Amanat Agung. Penafsiran lebih seksama dalam bahasa Yunani memperlihatkan bahwa kata ini bukan merupakan kata kerja pokok melainkan salah satu kata kerja pembantu.

Dari pengertian di atas, dapat dipahami bahwa perintah "pergi" bukan akhir dari tugas pemberitaan Injil. Diaz kemudian menjelaskan bahwa dalam Amanat Agung terdapat kata "disciple" yang merupakan satu-satunya perintah (langsung). Kata poreuthentes adalah bentuk participle maskulin jamak. Sesuai dengan teks asli kata ini berfungsi sebagai subyek (Diaz, 2014, p. 22). Schaeffer pun berpendapat bahwa perintah pergi bukanlah suatu keharusan kepada setiap penginjil yang dipahami dengan kewajiban pergi sejauh-jauhnya meskipun keputusan untuk melakukan penginjilan dengan berpindah dari satu tempat ke tempat lainnya tidak menjadi suatu hal yang salah. Schaeffer (2012) memberikan beberapa sumbangsih pemikiran sebagai kemungkinan untuk memaknai Matius 28:19a sebagai berikut:

1. "Karena itu, dengan telah pergi, jadikanlah semua bangsa murid" (sec. modal, agak harfiah)

2. "Karena itu, pergilah (sejauhjauhnya), jadikanlah semua bangsa murid" (tradisional) atau

3. "Karena itu, pergilah (turun dari bukit/marilah), jadikanlah semua bangsa murid" (minim) atau

4. "Karena itu, jika pergi (karena alasan apa pun), jadikanlah semua bangsa murid" (pragmatis)?

Schaeffer menambahkan, bahwa pada saat ini ada polemik yang mempertimbangkan apakah aspek "pergi" dapat dimengerti sebagai kesempatan; dapat dimanfaatkan yang terjadi karena mobilitas kehidupan yang menuntut perjalanan yang harus dilakukan (Schaeffer, 2012, p. 56). Namun jika mengacu pada pemahaman ini, Amanat Agung mungkin saja masuk dalam kegiatan situasional bukan perintah yang merupakan kewajiban. Sementara Darmawan mengemukakan bahwa teks Matius 28:18-20, setelah perintah pergi, memiliki pesan lanjutan yang sama 
penting, oleh sebab itu tugas gereja tidak hanya melaksanakan program untuk pergi tetapi pelaksanaan perintah selanjutnya (Darmawan, 2019, p. 145). Kendati artikel ini tidak menyalahi kegiatan misi untuk pergi ke daerah-daerah yang jauh, kesimpulan yang dikemukakan oleh penulis berdasarkan beberapa pandangan di atas adalah hal yang paling esensi dari Amanat Agung terdapat pada pemberitaan yang dilakukan dalam setiap aspek kehidupan orang percaya bukan yang dilakukan musiman atau dalam event tertentu saja.

Jika melihat dari teladan Tuhan Yesus saat melakukan pelayanan, pertama la pergi lalu la memilih orang-orang untuk dimuridkan dan membangun hubungan yang baik dengan mereka (Darmawan, 2019, p. 147). Para murid dipanggil untuk hidup bersama Tuhan Yesus sebagai bentuk pemuridan, salah satunya hubungan yang baik dengan muridmurid-Nya (Mat. 4:18-22). Mereka dipanggil untuk mengikuti Dia. Mengikuti Dia tidak sekadar dimaknai sebagai bentuk hadirnya para murid setiap saat ketika Tuhan Yesus sedang melayani. Keikutsertaan para murid sebagai bentuk upaya Tuhan Yesus untuk memuridkan mereka yang nanti akan meneruskan pemberitaan Kerajaan Sorga. Dalam banyak peristiwa selama pelayanan Tuhan Yesus, ajaran-Nya banyak ditujukkan bagi para murid, termasuk teguran-teguran yang Tuhan Yesus berikan seringkali untuk mengajar para murid yang sulit mempercayaiNya (Mat. 5-7).

Sesuai dengan apa yang Tuhan Yesus tunjukkan semasa pelayanan-Nya, "pergi" yang dilakukan oleh Tuhan Yesus berkaitan erat dengan pengajaran dan pemuridan yang dilakukan di sana. Seperti apa yang ditekankan oleh Matius, yaitu relasi antara Yesus dan para murid sebagai bentuk upaya Tuhan Yesus dalam pemuridan membawa mereka masuk dalam ruang lingkup-Nya, yaitu Kerajaan Sorga. Tuhan Yesus menghendaki teladan tersebut diteruskan oleh murid-murid-Nya, sementara pergi dan memberitakan Kabar Baik kepada segala bangsa, mengajar juga Dia lakukan.

Oleh sebab itu, kata pergi hendaknya dipahami sebagai suatu pergerakan yang perlu dilakukan orang percaya untuk menyuarakan keselamatan yang bersifat universal. Untuk menjangkau tempat yang berbeda demi memperluas komunitas orang percaya, upaya yang perlu dilakukan adalah pergi. Namun, tidak hanya sekadar pergi dan meninggalkan mereka yang telah percaya setelah memberitakan keselamatan, tetapi pergi untuk memuridkan. Sejajar dengan panggilan Tuhan Yesus yang pertama pada murid-murid-Nya. Mengikut Dia dan menjadi penjala manusia (4:19), merupakan perintah atau panggilan bagi murid-murid untuk memperluas dan memperbesar kelompok persekutuan mereka (Lowery, 2011, p. 42).

Demikian pula dengan kehadiran gereja, gereja hadir untuk membangun persekutuan dengan Kristus guna membangun iman para jemaat. Sebenarnya pelayanan Yesus sedang menunjukkan kepada murid-murid-Nya apa yang harus mereka lakukan dalam pelayanan dan berlanjut pada gereja masa kini, bahwa melalui gereja sebagai persekutuan tubuh Kristus, orangorang dapat memperoleh pertumbuhan iman melalui pemuridan yang dilakukan. Mereka belajar, bersedia diajar untuk hidup seperti Kristus. Apabila jangkauan setiap murid Kristus adalah segala suku bangsa maka yang menjadi pertanyaan apa yang diteruskan? Tentu saja pengajaran. Teks Matius 28:18-20 merupakan amanat Tuhan Yesus untuk memuridkan segala suku bangsa yang murid-murid-Nya temui untuk diteruskan bagi generasi berikutnya. Jadi, perintah pergi da- 
lam Matius 28:19a bukanlah sesuatu yang hanya dilakukan saat event terencana dalam sebuah program misi semata, bukan perintah yang dimaknai sebagai hal yang bersifat situasional, melainkan kesempatan untuk melaksanakan Amanat Agung yang dilakukan dalam setiap aspek kehidupan.

\section{“Jadikanlah Murid”}

Perintah langsung Amanat Agung, terletak pada kata "menjadikan murid". Maka arti literal dari perintah yang diwakili dua kata, "pergi" dan "jadikan murid" sebagaimana yang dikemukakan oleh Diaz adalah "karena itu, sementara pergi, jadikanlah murid". Artinya, perintah utama yang disampaikan yaitu "menjadikan murid" merupakan suatu mandat atau perintah yang harus dilakukan dalam setiap situasi (Diaz, 2014, p. 22). Inilah maksud dari perintah Tuhan Yesus, ke manapun murid-murid-Nya melangkah, sudah sepatutnya dengan kesadaran murid-murid melaksanakan Mandat Tuhan Yesus untuk menjadikan segala bangsa murid-Nya.

Pemuridan merupakan proses berkelanjutan yang dapat membuat orang Kristen bertumbuh secara rohani bahkan mencapai kedewasaan rohani (Gunawan, 2017, p. 6). Seseorang yang telah percaya perlu terus dibina untuk mengalami pemulihan hubungan dengan Allah. Tuhan Yesus memberikan amanat agar para murid pergi dan kemudian diikuti dengan perintah jadikanlah murid, karena setiap orang yang telah percaya harus bertumbuh dan mencapai kedewasaan rohani di dalam Dia, dan itu dapat tercapai melalui proses pemuridan. Proses menjadikan murid yang Tuhan Yesus lakukan adalah dengan mengajar para murid selama la melayani, untuk membina mereka agar dewasa secara rohani dan mampu menjalankan tugas besar ketika Tuhan Yesus naik ke sorga.
Tuhan Yesus dalam pemuridan-Nya yaitu dengan mengajar dan menjadikan para murid sebagai murid-murid-Nya adalah dengan tujuan supaya mereka melakukan hal yang sama (Subekti, 2019, p. 158). Dengan kata lain, para murid perlu menjadi murid terlebih dahulu sebelum mereka memuridkan orang lain di kemudian hari. Sebagaimana Gunawan memberikan pernyataan bahwa orang yang telah dewasa secara rohani akan mampu menjadi berkat bagi orang lain. Ketika ia dibina secara intens dan kemudian mengalami pemulihan bersama dengan Allah, ia mampu meneruskan hal tersebut kepada orang lain. Oleh sebab itu, orang yang telah dimuridkan dan mencapai kedewasaan rohani ia akan mampu memuridkan orang lain (Gunawan, 2017, p. 6).

Kata murid dalam bahasa Yunani matheteusate yang memiliki arti to be a disciple' atau 'to make a disciple' dapat dipahami juga sebagai perintah "muridkanlah", kata ini mengacu pada suatu perintah bahwa pada saat itu, orang-orang yang bersama Tuhan Yesus harus melakukan sesuatu setelah Tuhan Yesus naik ke surga, yaitu pergi untuk memuridkan. Kata ini juga dapat diartikan sebagai 'mengajar' yang artinya berkaitan dengan kegiatan pembelajaran. Kata matheteusate adalah verb imperative aorist active. Ruth Schaeffer menjelaskan:

Berbeda dengan terjemahan dalam bahasa Indonesia, dalam teks asli jelas bahwa perintah Yesus untuk "menjadikan semua bangsa murid" merupakan fokus kalimat Matius 28:19-20a. Hanya kata kerja ini berupa imperative/bentuk perintah seperti dinyatakan oleh akhiran kata (matheteusate = 'jadikanlah murid'), sedangkan tiga kata kerja lain dalam bentuk partisip, maka lebih mengekspresikan aspek-aspek tambahan (Schaeffer, 2012, p. 56). 
Menurut pandangan Schaeffer, apabila menyoroti teks asli secara khusus kata matheteusate, kata tersebut merupakan fokus dari perintah Tuhan Yesus dalam Matius 28:19-20. Dengan kata lain, yang menjadi inti dari Amanat Agung adalah proses memuridkan dan mengajarkan segala sesuatu yang telah Tuhan Yesus katakan dan lakukan selama la bersama-sama dengan murid-murid-Nya. Jika kembali pada sorotan Matius dalam tulisannya, ia memang menaruh perhatian yang signifikan terhadap ajaran Tuhan Yesus. Menjadi sejalan kemudian, ketika di akhir tulisannya Matius menegaskan perintah Tuhan Yesus kepada para murid terletak pada mengajar segala sesuatu yang telah disampaikan Tuhan Yesus kepada mereka.

Salah satu ajaran Tuhan Yesus adalah ajaran di bukit (Mat. 5-7) yang tidak boleh dikesampingkan, bahkan sangat penting bagi Matius. Khotbah di bukit bukan hanya sekadar bahan ajar atau khotbah yang diberikan kepada para murid sebagai pendengar, namun pengajaran di bukit adalah pengajaran sebagai barometer hidup para murid sebagai bagian dari komunitas Tuhan Yesus (Wisantono, 2019, p. 51). Hal ini masuk dalam pola pemuridan Tuhan Yesus menurut Matius yang sangat tertarik dengan apa yang Tuhan Yesus ajarkan kepada para murid, untuk dikerjakan oleh mereka di kemudian hari. Tidak heran jika Matius menyediakan ruang cukup panjang untuk menjelaskan ajaran-ajaran Tuhan Yesus dan bagaimana murid-murid harus hidup sesuai ajaran Gurunya, dengan janji bahwa Tuhan Yesus akan menyertai senantiasa sampai akhir zaman, sebagai bukti relasi yang baik dan pulih antara Guru dengan murid-murid-Nya (Mat. 28:20).

Hal yang menjadi pertanyaan, mengapa menjadikan murid begitu penting? Kenyataannya, Tuhan Yesus menghendaki agar para murid membentuk dan memperluas komunitas yang akan menjadi murid-murid selanjutnya. Mereka dibina untuk menjadi murid-murid yang harus dewasa secara spiritual. Artinya mereka hidup seperti apa yang Gurunya ajarkan dan seperti teladan yang ditunjukkan. Tuhan Yesus menghendaki agar komunitas yang telah diperluas tersebut adalah komunitas berisi orang-orang yang memiliki pertumbuhan iman yang baik dan terus bertumbuh. Sebagaimana upaya Tuhan Yesus untuk membina para murid-Nya, demikian la menghendaki agar kesebelas murid juga melakukan hal yang sama dalam penginjilan yang mereka kerjakan.

Implikasinya bagi gereja masa kini adalah gereja harus melakukan penginjilan dan pemuridan yang intens sebagai bentuk ketaatan pada perintah Allah untuk menghasilkan jemaat yang dewasa secara rohani. Barus mengatakan, "Proses pemuridan bukan alternative atau pilihan gereja, melainkan keharusan. Keharusan yang menjadikan gereja sebagai gereja." (2013, p. 14)

Barus menyimpulkan, sebagai utusan Kristus atau murid Kristus memuridkan bangsa lain adalah hal yang utama. Bahkan Barus menegaskan, bahwa memuridkan dan mengajar orang lain adalah bukti seorang murid yang memiliki Kristus di dalam hidupnya (Barus, 2013, p. 40). Komunitas yang disiplin dalam kerohanian adalah komunitas yang berhasil melaksanakan pemuridan dan pengajaran yang intens. Menjadi murid bukan sekadar persoalan kuantitas, tetapi saat ini gereja perlu mempertimbangkan pembinaan yang berkualitas untuk menghasilkan muridmurid Kristus yang juga berkualitas di mana ada Kristus di dalam diri mereka. Menjadi murid yang hidup seperti Gurunya dan siap untuk melakukan pemuridan selanjutnya, memperluas komunitasnya sampai ke ujung bumi sesuai dengan apa yang dikehendaki 
Tuhan Yesus ketika la memberi perintah kepada para murid-Nya.

Dengan kata lain, pemuridan juga upaya gereja untuk mempertahankan generasi yang kuat di dalam iman. Apabila gereja tidak melaksanakan pemberitaan Injil dan memuridkan mereka yang telah percaya, gereja menjauhkan diri dari kesempatan yang telah diberikan oleh Tuhan Yesus untuk mempersiapkan generasi yang berkualitas secara spiritual. Upaya gereja untuk penginjilan sebenarnya adalah bentuk kepedulian terhadap kemerosotan jumlah jemaat dengan mempertimbangkan pemuridan sebagai upaya mempertahankan dan membawa jemaat pada pertumbuhan iman. Tentu saja gereja bergerak untuk memperbanyak jemaat dari segi jumlah, tetapi gereja juga perlu bekerja keras untuk melakukan pemuridan agar jumlah yang banyak itu adalah orangorang yang berkualitas imannya.

\section{"Baptislah"}

Setelah Tuhan Yesus mengatakan bahwa setiap murid harus menjadikan segala bangsa murid-Nya. la memberikan perintah selanjutnya agar mereka membaptis orangorang yang telah mereka ajar atau muridkan. Perintah pemuridan pun tidak terlepas dari peristiwa baptisan. Kata "baptislah" berperan sebagai kata yang menyampaikan gagasan perintah muridkanlah (Diaz, 2014, p. 24). Hal ini bermakna sebagai langkah selanjutnya setelah seseorang menerima Tuhan Yesus menjadi Juruselamat. Sebagai tanda pertobatan, menjadi anggota jemaat dan seseorang yang telah memiliki hubungan dalam persekutuan. Hendi mengatakan:

Baptisan di sini merupakan tanda seseorang mengalami pertobatan dari dosa dan sekarang masuk ke dalam persekutuan dengan Allah melalui kuasa
Allah. Memuridkan semua bangsa berarti pergi keluar kepada mereka dan membawa mereka untuk mendapatkan pengampunan dari Allah dan masuk ke dalam persekutuan dengan Allah (Hendi, 2019, p. 54)

Jadi, perintah untuk membaptis dilakukan setelah seseorang memutuskan untuk percaya kepada Tuhan Yesus dan dibaptis dalam nama Allah Bapa, Anak, dan Roh Kudus. Baptisan adalah tanda yang melambangkan bahwa seseorang yang telah percaya tersebut adalah milik Kristus. Seseorang yang memberi diri untuk menjadi murid Kristus akan dibina, dan sebagai tanda bahwa ia telah menjadi bagian dari persekutuan gereja ia akan dibaptiskan. Memang benar bahwa kata "baptislah" dalam Yunani bukan kata perintah, melainkan participle yang memiliki fungsi sebagai subjek. Namun, sebagaimana yang disampaikan oleh Diaz, hubungan dan kedudukan kata ini dipengaruhi oleh kata kerja, maka kata ini disampaikan sebagai bentuk gagasan sebuah perintah (2014, p. 24).

Baptisan juga disebut sebagai tanda seseorang telah siap menjadi murid Kristus. Baptisan bukanlah sesuatu yang dilakukan untuk menerima keselamatan, melainkan sebagai tanda bahwa seseorang telah menerima keselamatan. Maka sebenarnya, baptisan melahirkan tanggung jawab yaitu untuk hidup sebagaimana Kristus hidup. Baptisan sebagai pernyataan bahwa ia telah percaya kepada Yesus sebagai Tuhan dan Juruselamat. Tuhan Yesus menghendaki agar setiap murid memperluas komunitasNya dengan mengundang mereka masuk dalam komunitas-Nya. Dengan dibaptis, gereja telah melakukan perintah Allah untuk membawa orang-orang masuk dalam komunitasNya yaitu sebagai jemaat dan murid Kristus. 
Dengan kata lain, baptisan adalah bentuk sambutan gereja untuk menerima anggota baru dalam persekutuan tubuh Kristus.

Setelah dibaptis hal yang perlu dikerjakan adalah mengajarkan segala sesuatu yang telah diperintahkan Tuhan Yesus kepada para murid. Pengajaran yang dikehendaki Tuhan Yesus adalah pengajaran yang bersifat intens atau terus-menerus guna mencapai kedewasaan spiritual. Ketika pengajaran dilakukan dengan baik, atau seseorang telah diajar dengan baik ia akan mampu mengajarkan orang lain dengan baik di kemudian hari.

\section{"Ajarlah"}

Kata didasko (Yun.) memiliki arti 'to teach'. Kata ini disebut 97 kali dalam Perjanjian Baru dan istilah ini seringkali mengacu pada kegiatan pelayanan Tuhan Yesus (Diaz, 2014, p. 28). Oleh sebab itu, "mengajar" atau "mengajarkan" bukanlah suatu hal yang dapat dipisahkan dari penginjilan. Karena bagian ini termasuk dalam perintah Tuhan Yesus untuk dilakukan sepanjang hidup para murid. Diaz (2014) memberikan keterangan tambahan, bahwa kata mengajar disampaikan oleh Tuhan Yesus dalam bentu present tense. Tidak ada batas waktu tertentu, maka jelas sekali apa yang Tuhan Yesus maksud adalah mengajar secara intens dan berkelanjutan.

Perintah mengajar merupakan suatu hal yang dilakukan terus-menerus tanpa batas waktu, apalagi kaitannya dengan proses pemuridan untuk menjadi murid Kristus, karena tujuannya adalah untuk menghasilkan murid-murid Kristus, tentu ini membutuhkan proses. Setelah percaya kepada Tuhan Yesus dan dibaptis, pemuridan akan berkelanjutan pada kegiatan mengajarkan segala sesuatu yang telah Tuhan Yesus ajarkan sebelumnya. Peristiwa baptisan bukan akhir dari proses yang dilakukan seorang murid da- lam melaksanakan Amanat Agung. Karena setelah dilakukan baptisan, masih ada tugas yang harus dilakukan secara terus-menerus yaitu mengajar. Perintah mengajar merupakan kata yang mengikuti ketiga perintah sebelumnya (Hartono, 2018, p. 6). Kesimpulannya adalah untuk menciptakan orang-orang yang mengalami pertumbuhan iman maka pengajaran perlu dilakukan (Darmawan, 2019, p. 149). Penekanan yang terlihat adalah secara menyeluruh Tuhan Yesus memberikan perintah kepada para murid untuk mengajar bukan untuk melakukan penyembuhan kepada orang banyak. Injil yang diberitakan dan harus diberitakan, adalah Kabar Baik yang dikumandangkan melalui pengajaran, topik ajaran adalah segala sesuatu yang telah Tuhan Yesus ajarkan kepada mereka.

Lowery mengelompokkan lima bagian utama yang fokus pada ajaran-ajaran Tuhan Yesus, yaitu: (1) Khotbah di bukit (Mat. 5-7), (2) Ajaran Misi (Mat. 10), (3) Ajaran tentang Perumpamaan-perumpamaan (Mat. 13:1-53), (4) Ajaran tentang Gereja (atau Persekutuan Mat. 18), dan (5) Khotbah tentang Akhir Zaman (Mat. 24-25) (Lowery, 2011, p. 43). Apa yang Tuhan Yesus ajarkan di kelas-kelas terbuka semasa pelayanannya di seluruh Galilea (4:23), bukan semata-mata membuat mujizat dengan menyembuhkan banyak yang sakit dan menjadi percaya. Tetapi Tuhan Yesus memberikan contoh sebagai Guru bagi murid-murid-Nya yang nanti akan ambil andil dalam pemuridan dengan pengajaran. Maka setiap ajaran Tuhan Yesus terus dilaksanakan oleh gereja-gereja masa kini sebagai pegangan komunitas dalam menjalani kehidupan. Tuhan Yesus memberikan ajaran demi ajaran untuk diteruskan oleh muridmurid ketika mereka mengajar orang-orang untuk percaya kepada Tuhan Yesus. 
Selain itu, Tuhan Yesus juga hidup sebagai model bagi para murid bukan hanya dari isi ajaran tetapi bagaimana melakukan ajaran tersebut. Maka, Tuhan Yesus menekankan bahwa para murid harus menjadi garam dan terang dunia, karena para murid diutus bukan hanya mengatakan tetapi hidup sesuai dengan apa yang mereka katakan, sebagaimana yang telah ditunjukkan oleh Tuhan Yesus dalam masa pelayananNya. Nilai-nilai moral dan ajaran tentang Kerajaan Sorga sebagai bahan ajar Tuhan Yesus kepada para murid, harus dihidupi oleh mereka untuk diteruskan kepada murid-murid selanjutnya. Matius sangat tertarik dengan apa yang Tuhan Yesus katakan, tetapi bukan berarti ia mengesampingkan apa yang Tuhan Yesus lakukan. Matius tetap menempatkan Tuhan Yesus sebagai teladan unggul dan Guru Agung yang ajaran-Nya harus ditaati. Bagaimana Tuhan Yesus ditampilkan sebagai Guru yang memiliki keinginan untuk membangun relasi yang baik dengan para murid sebab Kabar Baik ada di tengah-tengah mereka. Sebagaimana yang disampaikan oleh Wisantono, Matius juga menekankan ajaran Tuhan Yesus mengenai Kerajaan Allah bukan hanya sekadar pengajaran tetapi melalui perbuatan-perbuatan-Nya yang ajaib (2019, p. 53).

Selama pelayanan Tuhan Yesus yang dicatat oleh Matius, Tuhan Yesus juga melakukan banyak kejadian dahsyat sebagai bentuk penyataan bahwa la memiliki kuasa. Dengan kata lain, perkataan-Nya memiliki kuasa. Kuasa melakukan penyembuhan, berkuasa atas alam (8:23-27), dan kuasa untuk menghapus dosa (8:1-17). Jadi, apa yang Tuhan Yesus katakan ditaati bukan karena posisinya sebagai "guru" saja melainkan apa yang la katakan memiliki kuasa dan tidak dapat ditandingi oleh siapapun juga. Tuhan Yesus senantiasa membuktikan apa yang la katakan dengan tindakan dan bagaimana la hidup di dunia, baik ketika la dicobai dan dihadapkan pada penderitaan yang sedemikian rupa. Itulah ajaran penting Tuhan Yesus yang la kehendaki dilakukan oleh para murid-Nya yang la ajak bekerjasama denganNya untuk mengerjakan misi bagi keselamatan seluruh bangsa.

Matius, dalam tulisannya seolah-olah sedang menjelaskan bahwa Tuhan Yesus mulai mengajar dan menyembuhkan banyak orang, pasca dipanggilnya murid-murid-Nya yang pertama, yang akhirnya mengikut Dia dan hidup bersama dengan Dia (4:18-22). Upaya pemuridan Tuhan Yesus ingin dilihat secara langsung oleh para murid. Tidak hanya dalam kondisi belajar dan saat berada di dalam pelayanan, tetapi Tuhan Yesus ingin para murid menyaksikan apakah Dia merupakan Guru yang melakukan segala sesuatu yang telah la ajarkan. Tuhan Yesus mengajak para murid untuk mengikuti Dia dan hidup bersama dengan Dia, agar murid-murid-Nya dapat meniru teladan-Nya selama la melakukan pelayanan di dunia. Demikianlah yang harus dilakukan oleh mereka di hadapan murid-murid mereka selanjutnya.

Bagi Matius sendiri, Tuhan Yesus tidak ingin melayani seorang diri tanpa saksi-saksi yang bersama-Nya. Memahami bahwa pemuridan adalah suatu hal yang penting karena berisi pengajaran Kerajaan Sorga, tidak heran jika Tuhan Yesus tampil sebagai Guru yang berupaya menciptakan murid-murid yang akan menjadi guru selanjutnya dengan cara mengajar dan membina dalam waktu yang tidak sesaat. Wisantono menegaskan bahwa para murid menerima pesan sebagai perintah untuk melaksanakan pekerjaan yang telah Tuhan Yesus lakukan sebelumnya, yaitu mewartakan Injil dan memproklamirkan kuasa-Nya (2019, p. 55). Oleh sebab itu, Amanat Agung merupakan mandat yang 
harus dilakukan terus menerus, bukan sesuatu yang dikerjakan sesaat melainkan upaya setiap murid untuk mengajarkan segala sesuatu yang telah disampaikan oleh Tuhan Yesus dan menghidupi ajaran itu sampai la datang kedua kalinya. Apa yang Tuhan Yesus lakukan tidak hanya sekadar menyuarakan, tetapi mempersiapkan orangorang yang nantinya akan menyuarakan ajaran yang sama, yakni hal Kerajaan Sorga. Tuhan Yesus tidak selamanya berada di dunia sebagai manusia, maka Tuhan Yesus sebelum mengajar, memanggil murid-murid untuk dipersiapkan melanjutkan apa yang telah la ajarkan sampai kesudahan zaman. Menjadikan murid memang tidak lepas dari penginjilan (Henrichsen, 1977, p. 53), maka pergerakan untuk memberitakan Injil hendaknya disertai dengan proses pemuridan.

Perintah tersebut diakhiri dengan janji penyertaan sampai pada kesudahan zaman (Mat. 28:20). Tuhan Yesus mendapati beberapa dari murid-murid-Nya sekalipun menyembah tetap memiliki hati yang ragu, la memberikan suatu perintah yang harus dikerjakan dengan menjamin kehidupan mereka disertai oleh-Nya dan campur tanganNya selalu bersama dengan mereka. Mereka akan disertai selamanya sebab apa yang mereka akan lakukan adalah tugas besar yang harus dikerjakan sepanjang zaman.

\section{KESIMPULAN}

Matius membawa kita pada perenungan mendalam ketika kita mengikrar-

\section{DAFTAR RUJUKAN}

Barus, A. (2013). Pemuridan Sebagai Misi Gereja. Jurnal Amanat Agung 9(1), 184.

Darmawan, I. P. A. (2019). Jadikanlah Murid: Tugas Pemuridan Gereja Menurut Matius 28:18-20. Evangelikal: Jurnal kan janji dan komitmen untuk melakukan Amanat Agung sampai ke ujung bumi. Kita tidak mungkin menginjili tanpa meninggalkan ajaran-ajaran Tuhan Yesus, jika kita memahami bahwa setiap orang percaya harus bertumbuh secara spiritual. Teologi Matius memiliki keyakinan keselamatan universal yang diejawantahkan melalui pemuridan dan pengajaran. Kendati tulisan ini tidak menyalahi kegiatan misi pergi berpindah dari satu tempat ke tempat yang jauh, tetapi marilah kita kembali menyadari bahwa menyampaikan Kabar Baik tidak berhenti pada kegiatan pewartaan semata saat kita pergi, lantas meninggalkan orang yang baru percaya dengan Kitab Suci yang kita bagikan. Tetapi melakukan Amanat Agung adalah upaya gereja untuk mencetak murid-murid Kristus selanjutnya dengan kualitas spiritual dan iman yang terus bertumbuh. Ketika kita pergi meninggalkan mereka kabar keselamatan itu tidak hilang melainkan terus disuarakan sampai ke ujung bumi oleh muridmurid selanjutnya.

Pertanyaannya, apakah selama ini kita bergerak sebatas menjalankan suatu kegiatan misi dalam event tertentu atau kita bergerak sesuai dengan terang Alkitab, memberitakan Kerajaan Sorga dalam setiap situasi untuk memuridkan, mengajarkan segala sesuatu yang telah diajarkan Tuhan Yesus kepada kita dan mereka akan mengajarkan hal yang sama kepada murid selanjutnya?

Teologi Injili Dan Pembinaan Warga Jemaat 3(2), 144-153.

Diaz, B. N. (2014). Amanat Agung dan Pemuridan. Koinonia 8, 15-45. 
Gunawan, A. (2017). Pemuridan dan Kedewasaan Rohani. Jurnal Theologia Aletheia 19, 1-17.

Hartono, H. (2018). Mengaktualisasikan Amanat Agung Matius 28:19-20 dalam Konteks Era Digital 4(2), 157166

Hendi. (2019). Pemuridan Yang Disertai Kuasa dan Kehadiran Yesus: Analisis Colon Matius 28: 16-20. retrieved from https://osf.io/p5kub.

Henrichsen, W. A. (1977). Murid-murid Kristus Dibuat Bukan Dilahirkan. Bandung: Kalam Hidup.

Lowery, D. K. (2011). Teologi Matius. In $A$ Biblical Theology Of The New Testament. Malang: Gandum Mas.
Sarwono, J. (2006). Metode Penelitian Kuantitatif dan Kualitatif. Yogyakarta: Graha IImu.

Schaeffer, R. (2012). Mengapa "Menjadikan Semua Bangsa Murid" (Mat. 28:19)? Forum Biblika 26, 51-60.

Subekti, T. (2019). Pemuridan Misioner dalam Menyiapkan Perluasan Gereja Lokal. Epigraphe: Jurnal Teologi Dan Pelayanan Kristiani 3(2), 157-172.

Wisantono, S. (2019). Korelasi Konsep Kerajaan Allah dan Pemuridan dalam Injil Matius bagi Pemuridan Masa Kini. Veritas: Jurnal Teologi Dan Pelayanan 18(1), 45-67. 